\title{
A novel thiazolidine compound induces caspase-9 dependent apoptosis in cancer cells
}

\author{
F. Esra Onen-Bayram ${ }^{b, \dagger}$, Irem Durmaz $^{\mathrm{a}, \uparrow}$, Daniel Scherman ${ }^{\mathrm{c}}$, Jean Herscovici ${ }^{\mathrm{c}}$, Rengul Cetin-Atalay ${ }^{\mathrm{a}, *}$ \\ a Department of Molecular Biology and Genetics, Faculty of Science, Bilkent University, Bilkent, 06800 Ankara, Turkey \\ ${ }^{\mathrm{b}}$ Department of Pharmaceutical Chemistry, Faculty of Pharmacy, Yeditepe University, Kadlkoy, 34755 Istanbul, Turkey \\ ${ }^{\mathrm{c}}$ UMR 8151 CNRS, U1022 INSERM, Unité de Pharmacologie, Chimique et Génétique et d'Imagerie, Université Paris Descartes, Sorbonne Paris Cité, Chimie-Paris Tech., \\ 4 Avenue de l'observatoire, 75006 Paris, France
}

\section{A R T I C L E I N F O}

\section{Article history:}

Received 12 March 2012

Revised 16 May 2012

Accepted 10 July 2012

Available online 20 July 2012

\section{Keywords:}

Cytotoxic

Cancer

Thiazolidine

Terminal alkyne

Apoptosis

Caspase-9

\begin{abstract}
A B S T R A C T
The forward chemogenomics strategy allowed us to identify a potent cytotoxic thiazolidine compound as an apoptosis-inducing agent. Chemical structures were designed around a thiazolidine ring, a structure already noted for its anticancer properties. Initially, we evaluated these novel compounds on liver, breast, colon and endometrial cancer cell lines. The compound 3 (ALC67) showed the strongest cytotoxic activity $\left(\mathrm{IC}_{50} \sim 5 \mu \mathrm{M}\right)$. Cell cycle analysis with ALC67 on liver cells revealed SubG1/G1 arrest bearing apoptosis. Furthermore we demonstrated that cytotoxicity of this compound was due to the activation of caspase-9 involved apoptotic pathway, which is death receptor independent.
\end{abstract}

(c) 2012 Elsevier Ltd. All rights reserved.

\section{Introduction}

The recent development of proteomics, which is the study of protein structures and functions in large scale, has led to great improvements in anticancer drug research. ${ }^{1-3}$ Through this new field, novel anticancer targets have been identified, especially by using chemogenomics, an emerging powerful tool that screens small-molecule libraries to determine protein functions and drug candidates. ${ }^{4-8}$

Biological macromolecules involved in cancer cell growth mechanisms, metastasis, and tumor angiogenesis constitute the main targets of current anticancer drug studies. For instance, proteins involved in mitogenic signal transduction pathways like HER-29, ${ }^{9,10}$ and Bcr-Abl tyrosine kinases, ${ }^{11,12}$ have resulted in successful treatments of cancer patients. An alternative therapeutic strategy aims at developing apoptosis-inducing agents since apoptosis is a hallmark of oncogenic cell transformation. ${ }^{13,14}$

Apoptosis is a highly regulated cell death process that eliminates damaged or malfunctioning cells. It is characterized by DNA damage-induced chromatin condensation and cell shrinkage in early stage, followed by nuclear and cytoplasmic fragmentation,

\footnotetext{
* Corresponding author. Tel.: +90 312290 2503; fax: +90 3122665097.

E-mail address: rengul@bilkent.edu.tr (R. Cetin-Atalay).

+ These authors contributed equally to this work.
}

resulting in the phagocytosis of membrane-bound apoptotic bodies. Apoptosis can be triggered by various external or internal stimuli. Depending on its origin (external or internal) the stimulus can activate one of two signaling pathways. Both pathways involve aspartate-specific cysteine proteases or caspases that can be classified into two groups: initiator caspases and effector caspases.

The caspases form a cascade that induces the transduction and signal amplification of apoptotic pathways. Initiator caspases such as caspase- 8 and caspase- 9 activate effector caspases upon apoptotic signals. These caspases can then activate effector caspases, such as caspase-3. In turn, the effector caspases cleave key cellular proteins, which lead to the morphological changes observed in cells undergoing apoptosis.

In this study, we aimed to develop a novel anticancer agent to activate apoptosis-induced cell death in cancer cell lines. We synthesized a library of small-molecules around a thiazolidine moiety, as this structure is already noted for its anticancer properties and thiazolidine derivatives were shown to induce apoptosis in various cancer cells. ${ }^{15-20}$ Further, the thiazolidine heterocycle allows a diverse range of molecular structures in only a few transformations. We investigated synthesized compounds for their cytotoxicity to several human cancer cell lines and performed analyses to the cell deaths induced the novel structures. 


\section{Results}

\subsection{Preparation of the small-molecule library}

The library of tested molecules was developed around a thiazolidine core. Three different series of compounds (pyrimidic derivatives, a benzoyl derivatives and $\mathrm{N}$-acetylated triazoles) were prepared (Chart 1 ). We have described the synthetic procedures leading to these structures elsewhere. ${ }^{21}$

\subsection{Identification of cytotoxic activity in cancer cell lines}

Preliminary results of the anticancer activity of the synthesized molecules were obtained using the Giemsa staining, a qualitative technique in which the dye binds to DNA and allows visualization of cells attached to culture plates. Cytotoxic effects were monitored on Huh7 hepatocellular carcinoma (HCC) cell lines. The assay resulted in identifying the lethal effect of the terminal alkyne precursor of triazoles obtained by acylation of the thiazolidine ring in the presence of propiolic acid (Scheme 1). None of the remaining compounds inhibited cell growth (Fig. 1).

From the molecules synthesized and evaluated with Giemsa, four representative compounds were selected (one thymine derivative $\mathrm{R}=\mathrm{C}\left(\mathrm{CH}_{3}\right)_{3}$, one benzoyl derivative $\mathrm{R} 1=\left(\mathrm{CH}_{2}\right)_{2}$-thiophene $\mathrm{R} 2=\mathrm{C}\left(\mathrm{CH}_{3}\right)_{3}$ and two triazoles $\mathrm{R}=$ thiophenethyl and $\mathrm{R}=$ aminocyclohexyl) for a sulforhodamine B (SRB) assay, in addition to compound 3 (ALC67). We confirmed our initial Giemsa assay results by SRB assays on liver, colon, and breast cancer cell lines. Except for ALC67, none of the compounds showed significant cytotoxicity (Fig. 2).

The quantification of the in vitro antitumor activity of ALC67 was screened on various liver (Huh7, HepG2, Mahlavu, FOCUS), breast (T47D, MCF7, BT20, CAMA-1), and endometrial (MFE-296) cancer cell lines using the SRB assay according to the US' National Cancer Institute guidelines. The cytotoxic activity of ALC67 was compared to that of camptothecin (CPT) and 5-fluorouracil (5FU), well-known anticancer agents. Promising micromolar $\mathrm{IC}_{50}$ values were obtained for all the tested cell lines (Table 1). The cytotoxicity of this compound was further confirmed by real-time cell analysis (RT-CA), which is based on a time-dependent measurement of the electrical impedance of attached (thus living) cells during chemical treatment (Fig. 3). Observed cell death percentages in the RT-CA with $\mathrm{IC}_{100}$ and $\mathrm{IC}_{50}$ concentrations (determined from the SRB assays (Table 1)) were highly correlated, except for the Huh7 and CAMA-1 cells. In Huh7, 100\% cell death occurred for both
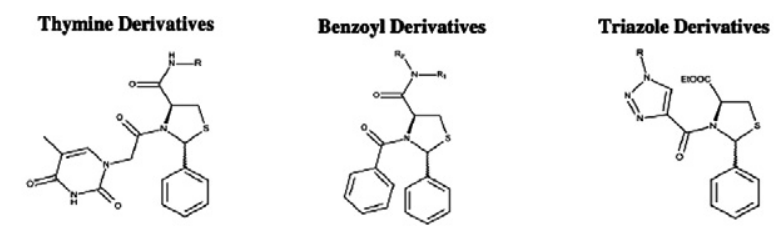

$\mathbf{R}=$

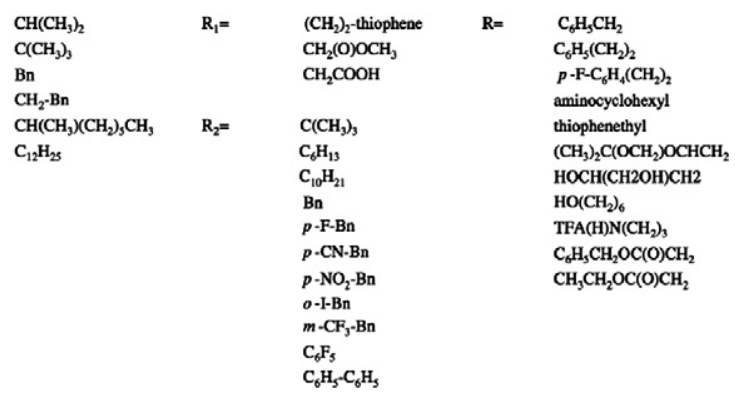

Chart 1. Structures of synthesized thiazolidines.

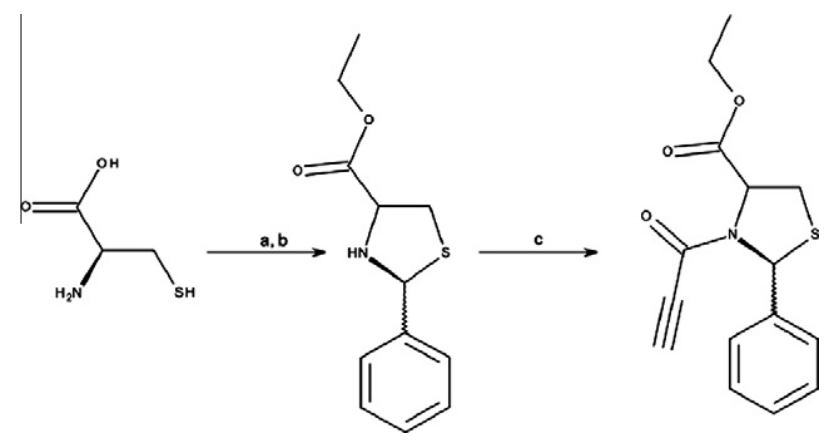

Scheme 1. Reagents: (a) benzaldehyde in $\mathrm{C}_{2} \mathrm{H}_{5} \mathrm{OH}, \mathrm{H}_{2} \mathrm{O}$ (1/1); (b) $\mathrm{SOCl}_{2}$ in absolute $\mathrm{C}_{2} \mathrm{H}_{5} \mathrm{OH}$; (c) propiolic acid, DCC in dry $\mathrm{CH}_{2} \mathrm{Cl}_{2}$.
A

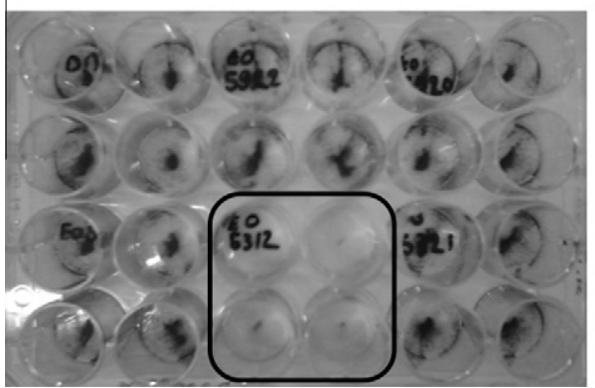

B

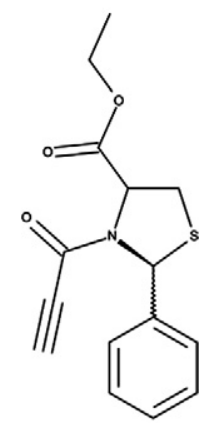

Figure 1. (A) Giemsa staining of Huh7 cell lines with various thiazolidines; cell death induced by ALC67 is shown in framed wells. (B) The structure of the active compound 3 (ALC67), the (2RS, 4R)-2-Phenyl-3-propionyl-thiazolidine-4-carboxylic acid ethyl ester.

concentrations ( 10 and $5 \mu \mathrm{M}$ ). On the other hand, CAMA- 1 showed a low cell death ratio even in $\mathrm{IC}_{100}$ concentrations $(0.02 \mu \mathrm{M})$. CAMA-1 cells grows in multilayers therefore the observed electrical impedance may not reflect the real cell growth.

\subsection{Characterization of the cell deaths induced by ALC67}

The key feature of apoptotic cell death is DNA fragmentation due to the activation of endogenous endonucleases. The terminal deoxynucleotidyl transferase dUTP nick end labeling (TUNEL) assay is a method that detects fragmented DNA by labeling the terminal ends of nucleic acids. The condensed nuclei observed in ALC67-treated cancer cells revealed that DNA damage in those cells is most likely due to apoptosis (Fig. 4). Upon apoptotic stimuli, the mitochondrial outer membrane permeabilizes and cytochrome $\mathrm{c}$ is released in to the cytoplasm. Because ALC67 induced apoptosis, we aimed to check the cytochrome $c$ release in the presence of this compound via immunostaining. And indeed, apoptosis bearing diffuse cytochrome c staining confirmed its induction by ALC67 (Fig. 4).

\subsection{Cell cycle arrest induced by ALC67}

The apoptotic effect of ALC67 on the cell cycle was further characterized by fluorescence-activated cell sorting (FACS) analysis, using a propidium iodide stain. This analysis revealed the SubG1/ G1 cell cycle arrest in ALC67-treated Huh7 and Mahlavu cells compared to control cells treated with DMSO (Fig. 5). Untreated HCC Huh7 and Mahlavu cells showed a normally cycling cells FACS spectrum, whereas treatment with ALC67 led to cell cycle arrest at the SubG1/G1 phase (Fig. 5). 

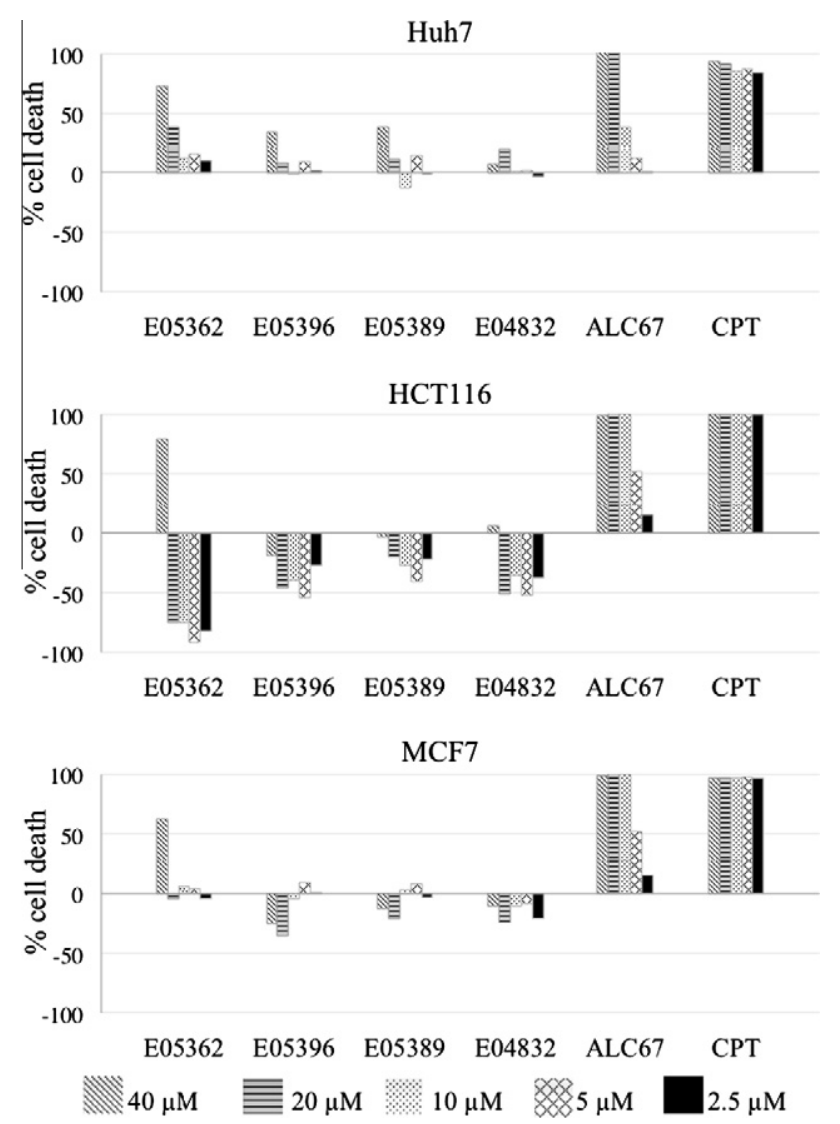

Figure 2. Percent cell death on liver (Huh7), colon (HCT116), and breast (MCF7) cancer cell lines induced with increasing concentrations $(2.5-40 \mu \mathrm{M})$ of selected compounds E05362 (triazole derivative $\mathrm{R}=$ thiophenethyl), E05396 (benzoyl derivative $\mathrm{R}^{1}=\left(\mathrm{CH}_{2}\right)_{2}$-thiophene, $\left.\mathrm{R}^{2}=\mathrm{C}\left(\mathrm{CH}_{3}\right)_{3}\right)$, E05389 (triazole derivative $\mathrm{R}=$ aminocyclohexyl), E04832 (thymine derivative $\left.\mathrm{R}=\mathrm{C}\left(\mathrm{CH}_{3}\right)_{3}\right)$, and ALC67. Treatment was performed for $72 \mathrm{~h}$ in triplicate. NCI-SRB analysis was then applied as explained in the Methods section. Absorbance values were normalized according to the DMSO control and Tz. Camptothecin (CPT) was used as a positive control. The results are representative of three independent experiments; S.D.s are less than $10 \%$.

Table 1

$\mathrm{IC}_{50}$ values of ALC67 in a series of cancer cell lines

\begin{tabular}{lllll}
\hline Tissue & Cell line & ALC67 IC $_{50}{ }^{\mathrm{a}}(\mu \mathrm{M})$ & CPT IC $_{50}(\mu \mathrm{M})$ & 5FU IC \\
50 & $(\mu \mathrm{M})$ \\
\hline \multirow{2}{*}{ Liver } & HepG2 & $10.0 \pm 1.5$ & 0.01 & 5.7 \\
& Huh7 & $5.3 \pm 0.93$ & 0.15 & 30.7 \\
& MV & $0.41 \pm 0.5$ & $<1$ & 9.97 \\
& FOCUS & $5.47 \pm 1.5$ & $<1$ & 7.69 \\
Colon & HCT116 & $9.23 \pm 0.89$ & $<1$ & 18.7 \\
Breast & T47D & $7.62 \pm 1.73$ & $<1$ & 8.91 \\
& MCF7 & $4.7 \pm 0.81$ & $<1$ & 3.5 \\
& BT20 & $1.6 \pm 0.56$ & 0.07 & 47.30 \\
\multirow{5}{*}{ Endometrial } & MFE- & $0.01 \pm 0.42$ & 0.07 & 1.28 \\
& MFE- & $0.5 \pm 0.3$ & $<1$ & 30.68
\end{tabular}

a The experiments were performed in triplicate and standard deviations are shown with \pm .

\subsection{Investigation of the caspase dependency of apoptosis}

To determine the apoptotic pathway that is implied in the detected cell death induced by ALC67, we examined the independent activities of caspase- 8 and caspase- 9 by inactivating caspase- 3 and -9 , or caspase- 8 and -3 , respectively, using specific inhibitors.

Prior to treatment with ALC67 $(10 \mu \mathrm{M})$, HepG2 cells were incubated for $24 \mathrm{~h}$ with one of the following compounds: the caspase9-specific inhibitor z-LEHD-fmk $(50 \mu \mathrm{M})$ in order to normalize
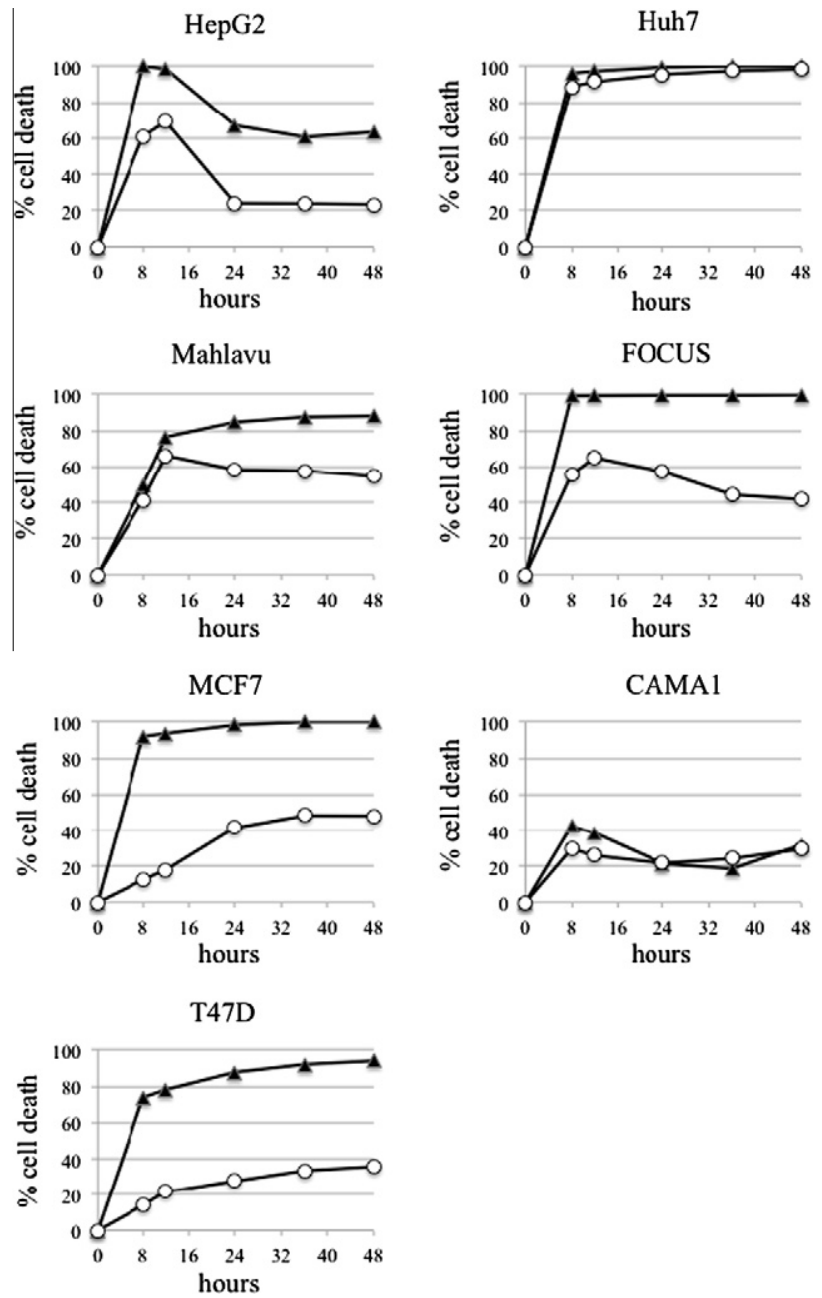

Figure 3. Real-time percent cell death monitoring for $72 \mathrm{~h}$ was performed in the presence of ALC67 with the $\mathrm{IC}_{50}$ (empty circle) and $\mathrm{IC}_{100}$ (solid triangle) concentrations of Table 1 . The effect of the compound on cell growth was analyzed using xCELLigence software. The experiment was done in triplicate; the results were normalized to the DMSO controls and Tz. The experiments were performed in triplicate and standard deviations were less $10 \%$.

caspase-9 activity; the caspase-8-specific inhibitor z-IETD-fmk $(50 \mu \mathrm{M})$ to quantify caspase-9's activity when caspase-8 is inactivated; or the caspase-3-specific inhibitor z-DEVD-fmk $(50 \mu \mathrm{M})$ to quantify caspase- 9 activity when caspase- 3 is inactivated. The addition of ALC67 led to a significant increase in the activity of caspase-9 (Fig. 6A). Interestingly, such a treatment did not induce any increase when caspase- 3 or caspase- 8 were inhibited by their specific peptide inhibitors (z-DEVD-fmk and z-IETD-fmk, respectively). As depicted in Figure 6A the normalized values were found to be smaller than 1 . These results indicated a central role of caspase- 9 in the cell death process induced by the terminal alkyne structure.

Using the same experimental set-up, we also tested the pathway exhibiting caspase- 8 activity but normalized it with the caspase- 8 inhibitor. Therefore, initially, HepG2 cells were incubated for $24 \mathrm{~h}$ with one of the caspase inhibitors (the caspase-8-specific inhibitor z-IETD-fmk $(50 \mu \mathrm{M})$, the caspase-9-specific inhibitor $z$ LEHD-fmk $(50 \mu \mathrm{M})$, the caspase-3-specific inhibitor z-DEVD-fmk $(50 \mu \mathrm{M}))$ or without any of them. Then cells were further treated with ALC67, excluding the test tube with the z-IETD-fmk. After $12 \mathrm{~h}$, caspase- 8 activity was assessed. Our normalized results demonstrated that treatment of HepG2 cells with ALC67 does not 


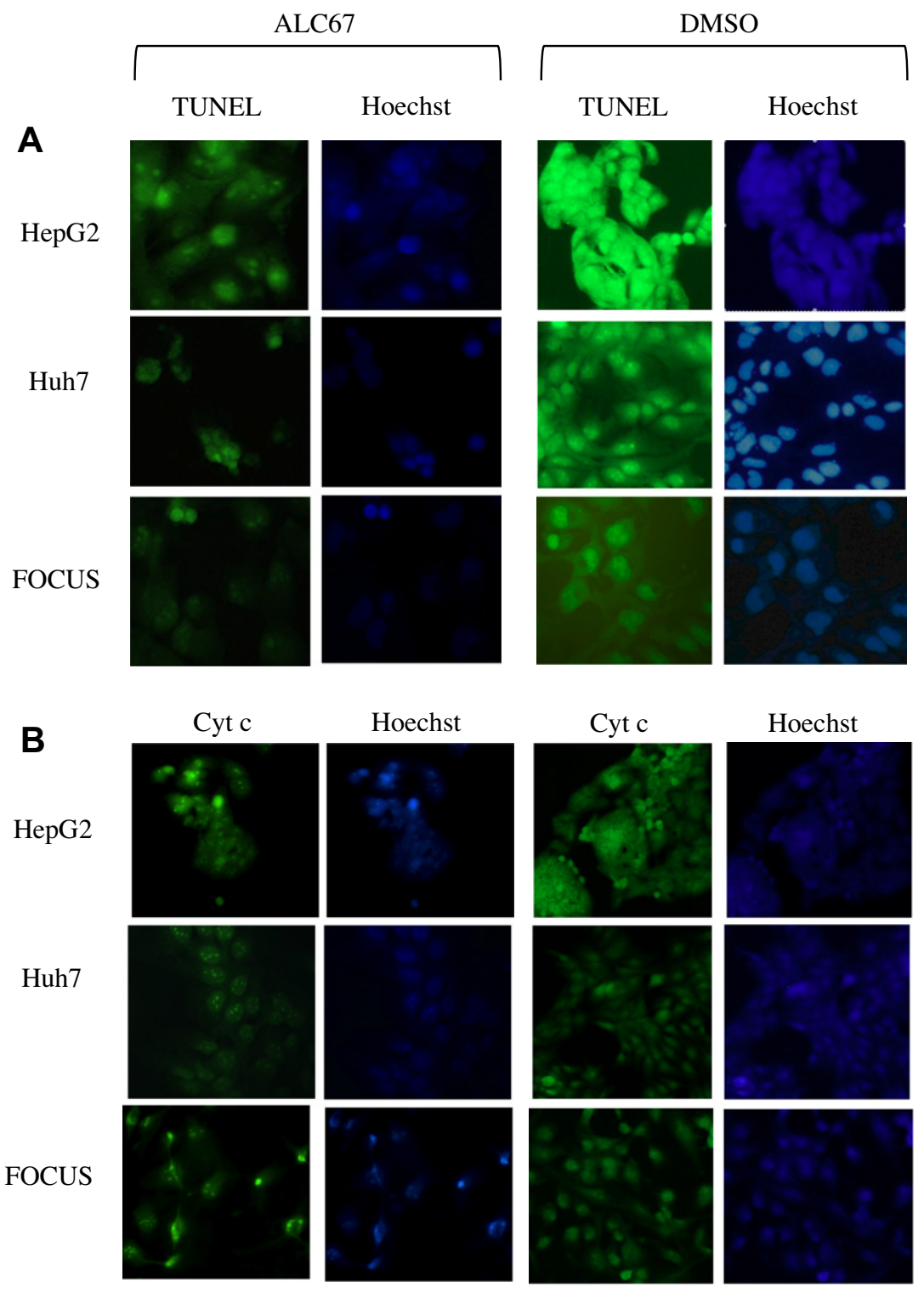

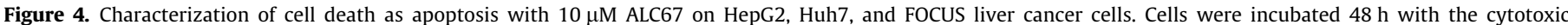

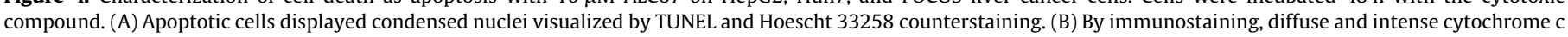
release from mitochon dria due to apoptosis can be observed in the presence of ALC67.

induce significant activation of caspase- 8 even when caspase- 9 or caspase-3 is inhibited (Fig. 6B).

In order to confirm the caspase-9 dependent apoptotic pathway activation by ALC67, we examined the cleavage patterns of caspase- 3 , caspase- 9 and caspase- 8 using specific antibodies. Huh7 cells were incubated for 6,12 or $24 \mathrm{~h}$ with ALC67 $(2.5 \mu \mathrm{M}$ and $5 \mu \mathrm{M})$ or DMSO controls. Treatment with ALC67 caused cleavage of caspase- 9 and therefore activation of its downstream element caspase-3 (Fig. 7A-C). However, caspase- 8 was observed as intact protein hence the cleaved products of caspase- 8 at 43 or $18 \mathrm{kD}$ was not observed (Fig. 7A, D).

This result is in correlation with the caspase activity assay demonstrated in Figure 6, suggesting that ALC67 treatment induced caspase-9 dependent apoptotic pathway resulting in caspase-3 cleavage and apoptotic cell death.

\section{Discussion}

Although the anticancer property of thiazolidinones was established some time ago, ${ }^{16,22-26}$ analysis of the antiproliferative activity of thiazolidine rings has emerged only recently. ${ }^{16-20}$ The easy, efficient, and rapid introduction of diverse moieties of this five-membered heterocycle to several sites allows the rapid generation of small-molecule libraries bearing this core structure. The recent identification of the anticancer property of 2-arylthiazolidine4-carboxylic acid amide compounds led us to design a chemical library around the 2-phenylthiazolidine-4-carboxylic acid structure. Substituting the secondary amine of the heterocycle has not yet been investigated, therefore we synthesized N-acylated structures to develop novel anticancer agents. Also, given the recent description of the anticancer activity of some 1-thiazolyl-1,2,3-triazoles $^{27}$ and our expertise on the generation triazoles with supported $\mathrm{Cu}(\mathrm{I})$ catalysts, ${ }^{28,29}$ we decided to generate a library with not only benzoyl and pyrimidine derivatives but also 1,2,3triazoles.

When their antitumor activity was evaluated, none of the triazoles gave satisfactory results but, interestingly, their alkyne precursor presented a considerable impact on hepatocellular, breast, colon, and endometrial cancer cell lines due to micromolar $\mathrm{IC}_{50}$ values that the molecule exhibited. The detection of apoptotic 
A
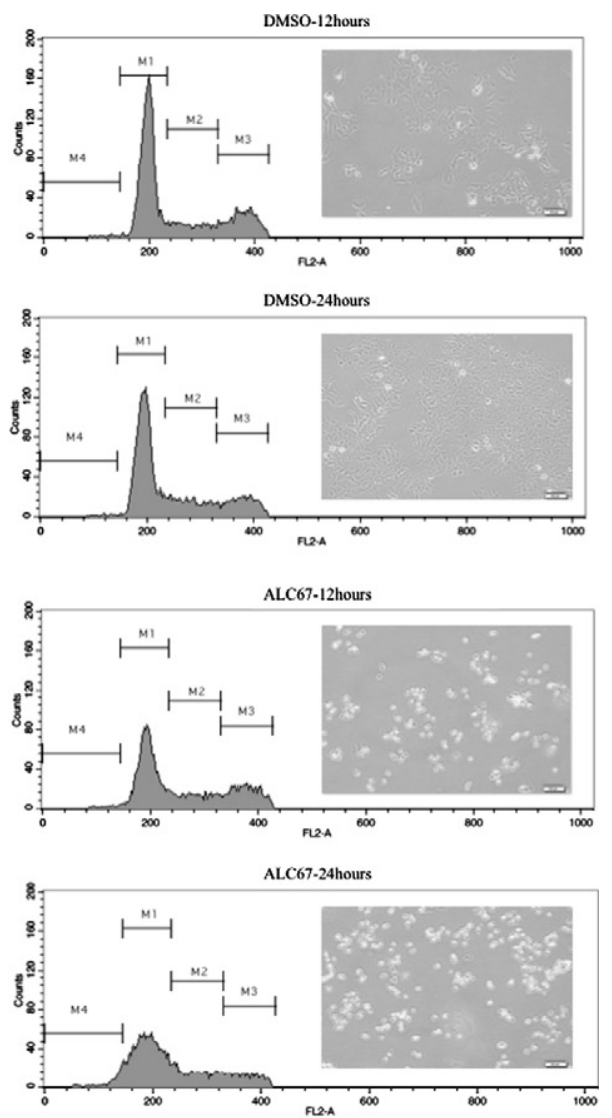

B
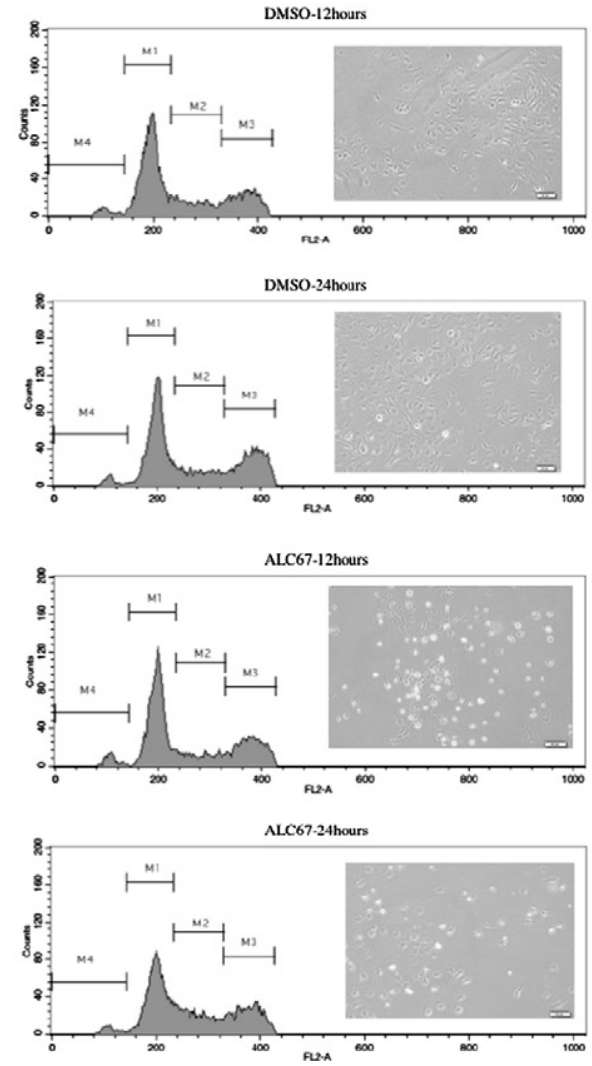

Figure 5. Cell cycle distribution analysis was performed on (A) Huh7 and (B) Mahlavu liver cancer cells, which were treated with either DMSO or ALC67 $(5 \mu \mathrm{M})$ for $12 \mathrm{~h}$ and $24 \mathrm{~h}$. Then FACS analysis was performed. The peak at 200 FL2-A represents $2 \mathrm{~N}$ cells (G1-phase) and the peak at 400 represents $4 \mathrm{~N}$ cells (G2-phase). The peak in-between represents S-phase cells. During gating, $>4 \mathrm{~N}$ cells were excluded since they showed no variation between control and treated cell groups.
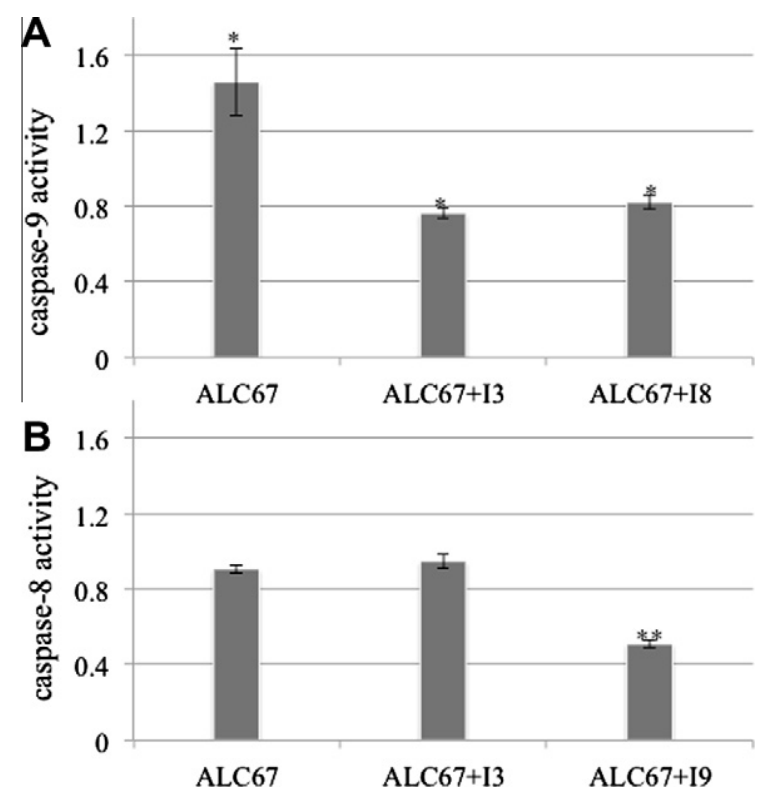

Figure 6. Caspase activity assay with HepG2 cells. Cells were incubated with ALC67 in the absence and $50 \mu \mathrm{M}$ presence of various caspase inhibitor peptides: z-IETDfmk, z-LEHD-fmk, and z-DEVD-fmk for caspase-8, caspase-9, and caspase-3, respectively. Then (A) caspase- 9 and (B) caspase- 8 activities were evaluated after a further $12 \mathrm{~h}$ of incubation in the presence of ALC67. Two independent experiments were performed in duplicate. Endogenous caspase-9 (A) and caspase-8 (B) activities were calculated in the absence of ALC67 with their associated peptide inhibitors, to which drug-treated caspase activity values were normalized and represented. The values ${ }^{*} p$-value $<0.05$ ( $t$-test) were compared with cells treated with the caspase-9-specific inhibitor z-LEHD-fmk only; ${ }^{* *} p$-value $<0.05$ ( $t$-test) were compared with cells treated with the caspase-8-specific inhibitor z-IETD-fmk only.

morphologies using several staining assays and the confirmation of the cell death process by additional molecular biology techniques revealed the apoptotic property of this novel cytotoxic compound.

The diversity of stimuli that can activate and regulate apoptosis is extensive, and so is the diversity of signaling pathways that lead to apoptosis. The extrinsic pathway is triggered by the activation of death receptors, which recruit caspase- 8 and either directly activate caspase- 3 to lead to apoptosis (Fig. 8, pathway 1 ) or activate a cascade of proteins that stimulates the activity of caspase- 9 and caspase-3 (Fig. 8, pathway 2). Another apoptosis route starts with microtubule or DNA damage, which trigger the activation of a cascade of proteins, leading to the activation of caspase- 9 and 3 (Fig. 8, pathway 3). In order to determine the caspases involved in the apoptotic mechanism triggered by the cytotoxic thiazolidine compound ALC67, we investigated the activities of caspases- 8 and -9 , maintaining or repressing the activities of caspase- 3 and -9 or caspase- 3 and -8 respectively. Alteration of caspase- 8 activity was not observed in the presence of ALC67; thus the extrinsic apoptotic pathway activated by death receptors does not seem to be the one that leads to the observed cell death. To determine whether the intrinsic apoptotic pathway was involved in ALC67induced cell death, the activity of caspase- 9 in the presence of this molecule was evaluated and a significant increase was detected. Our results indicated that ALC67 stimulated the intrinsic apoptotic pathway, a finding, consistent with our cytochrome c assay results (Fig. 4). The release of cytochrome $c$ in the cytosol is widely accepted to be responsible for the activation of caspase-9; once activated, caspase- 9 activates caspase- 3 , which eventually results in the execution of programmed cell death. ${ }^{30,31}$ Moreover, recent studies have revealed the existence of a caspase-3-dependent positive feedback loop that amplifies caspase- 9 activity ${ }^{32-34}$ This 

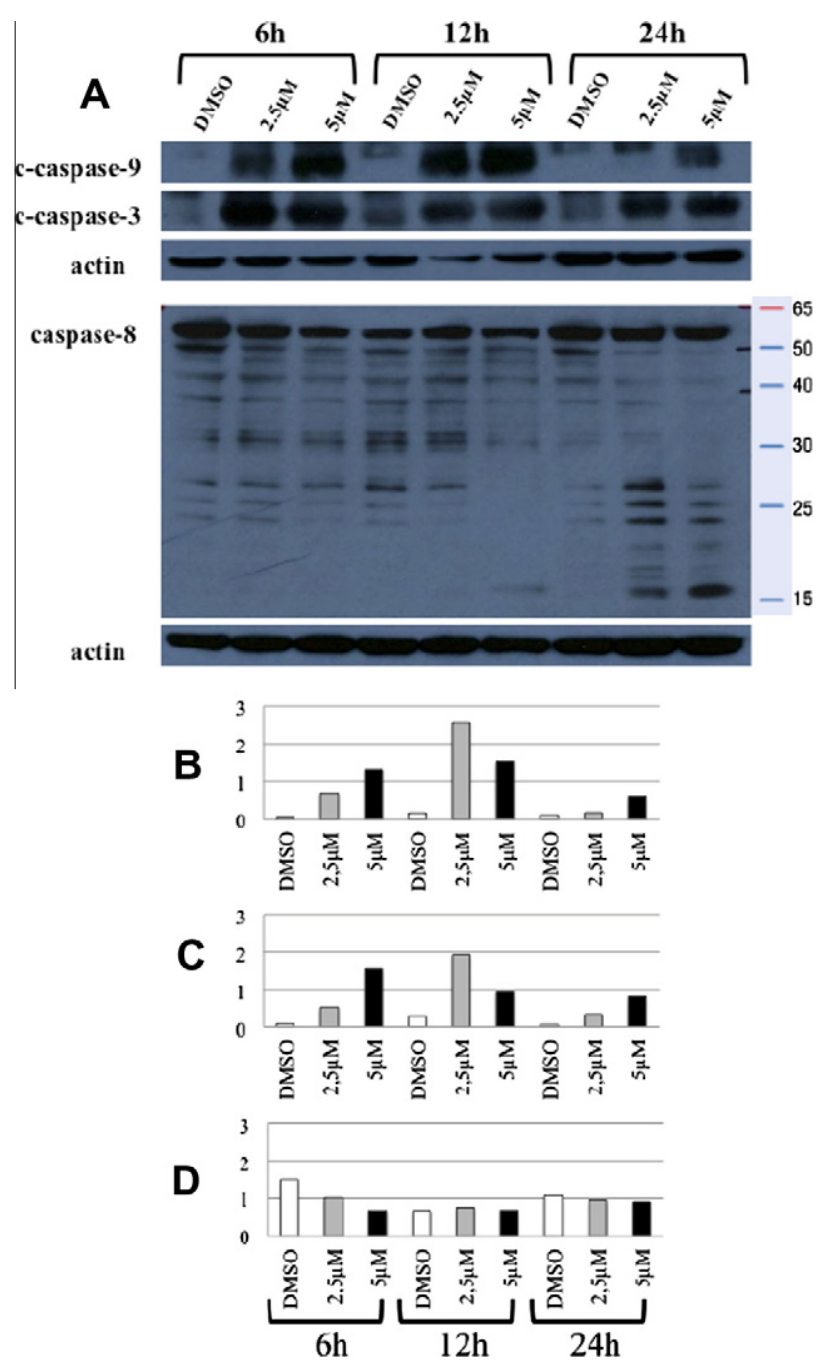

Figure 7. Caspase cleavage in ALC67 treated Huh7 cell lines. Cells were treated with 2.5 or $5 \mu \mathrm{M}$ ALC67 or DMSO control and incubated for 6,12 or $24 \mathrm{~h}$. Then (A) activities of caspase- 9 , caspase- 3 and caspase- 8 were analyzed by their cleavage status using specific antibodies against cleaved caspase-9 (c-caspase-9), cleaved caspase- 3 (c-caspase- 3 ) and cleaved and intact caspase- 8 by western blot analysis. Cleaved caspase- 8 fragments at 43 and $18 \mathrm{kD}$ were not observed. c-caspase- 9 and ccaspase- 3 were analyzed on the same membrane with anti-goat and anti-rabbit secondary antibodies respectively. Actin is used for equal loading control. Quantification of the gel documents of (B) cleaved-caspase-9, (C) cleaved-caspase-3 and (D) caspase- 8 were calculated by TotalLab Quant software and normalized to actin.

result could explain the inactivation of caspase- 9 when cells are treated by both the cytotoxic molecule and the caspase- 3 inhibitor. Furthermore, our results also displayed a crucial role for caspase- 8 in the maintenance of caspase- 9 activity, a finding in line with previous studies showing the amplifying role of caspase- 8 in addition to caspase- 3 in Taxol-induced apoptosis. ${ }^{35,36}$ In addition, the activation of caspase- 9 in the presence of ALC67 suggests a possible interaction of the molecule with proteins involved in the mitochondrial apoptotic signaling pathways. ALC67 induced caspase-9 activation was further confirmed with western blot analysis using specific antibodies against cleaved forms of caspase-9, caspase-3. We were unable to observe any bands in cleaved forms of caspase- 8 , which are expected to be 43 and $18 \mathrm{kD}$ but inactive intact form of caspase- 8 was observed significantly. In order to determine which proteins are involved microarray analyses could be performed as modifications in gene expression levels can determine which signaling pathways are disrupted by the presence of the cytotoxic compound, and consequently reveal its target proteins.

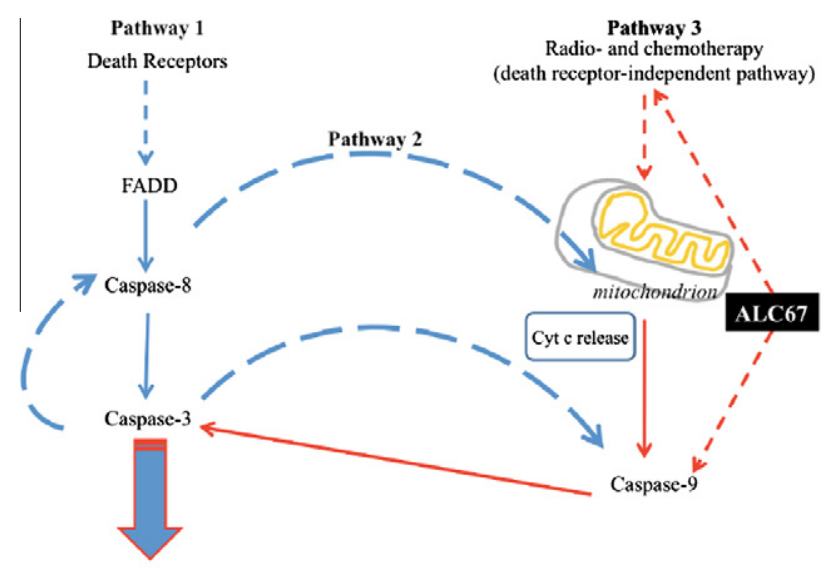

\section{APOPTOSIS}

Figure 8. Schematic representation of caspase-9- and -8-dependent apoptotic pathways and the putative effect of ALC67 on apoptosis-induced cell death. Dashed lines represent signaling with more than one protein component.

Fluorescent activated cell sorting analysis was performed to assess the effect of ALC67 on the cell cycle. The results indicated that ALC67 induced SubG1/G1 arrest compared to DMSO-treated controls, which did not (Fig. 5). Most of the time, SubG1/G1 arrest is related to apoptosis induction; moreover, this observation correlated with the results of caspase activity assay that showed that our novel compound induced caspase- 9 activity and therefore the intrinsic apoptotic pathway.

Finally, as no lethal effect was observed either with the 2-phenylthiazolidine-4-carboxylic acid ethyl ester, namely the non-acylated thiazolidine (2) or with the triazoles resulting from the bioactive alkyne (ALC67), the toxicity could be attributed to the three-dimensional organization of the molecule and/or the presence of the terminal alkyne moiety. The importance of the presence of a terminal alkyne for cytotoxicity to be acquired has already been described for several anticancer agents. These similar compounds are reported to be nucleoside analogues, such as for 3'ethynylcytidine (ECyd) and 3'-ethynyluridine (EUrd) ${ }^{37-39}$, or acetylenic antifolates such as $\mathrm{CB} 3717^{40,41}$ or pralatrexate, ${ }^{42,43}$ which were approved in 2009 as the first anticancer agents for the treatment of relapsed or refractory peripheral T-cell lymphoma (PTCL). ${ }^{44-46}$ A structure-activity relationship (SAR) study that aims on the one hand to analyze the impact of this moiety and on the other hand to improve the bioactivities is currently in progress. It is also necessary to analyze the impact of the conjugated carbonyl moiety on the bioactivity since electrophilic centers can trigger glutathione depletion and hence apoptosis. ${ }^{47}$ Thus in addition to the conjugated analogues, propargylamine derivatives will also be evaluated in the SAR study.

In this study, a library of thiazolidine compounds was synthesized and their cytotoxic activity was evaluated. An alkyne compound, ALC67, was identified as cytotoxic to liver, colon, breast, and endometrial cancer cells, with comparable $\mathrm{IC}_{50}$ values to that of CPT and 5-FU. The investigation of the nature of the cytotoxic effect of ALC67 led determining an apoptotic property that triggers caspase- 9 activity and therefore SubG1/G1 arrest.

\section{Experimental section}

\subsection{Synthesis of the active compound: $(2 R S, 4 R)-2-P h e n y l-3-$ propionyl-thiazolidine-4-carboxylic acid ethyl ester}

\subsection{1. (2RS, 4R)-2-Phenylthiazolidine-4-carboxylic acid (1)}

Sodium hydroxide pellets $(2.28 \mathrm{~g}, 56.9 \mathrm{mmol})$ were added to a solution of L-cystein hydrochlorate monohydrate $(10.0 \mathrm{~g}$, 
$56.9 \mathrm{mmol})$ in water $(37 \mathrm{~mL})$. After complete dissolution, successively, ethanol $(11 \mathrm{~mL})$, benzaldehyde $(5.78 \mathrm{ml}, 56.9 \mathrm{mmol})$, and ethanol $(30 \mathrm{~mL})$ were added and the mixture was stirred for $3 \mathrm{~h}$ at room temperature. The resulting precipitate was filtered and washed with water before being dried under vacuo to lead to the expected compound quantitatively $(11.9 \mathrm{~g})$.

${ }^{1} \mathrm{H}$ NMR (DMSO- $\left.d_{6}\right) \delta 3.07-3.16(\mathrm{~m}, 1 \mathrm{H}), 3.26-3.39(\mathrm{~m}, 1 \mathrm{H}), 3.86$ (dd, $J=9.0,7.8 \mathrm{~Hz}, 0.4 \mathrm{H}), 4.22$ (dd, $J=7.2,4.5 \mathrm{~Hz}, 0.6 \mathrm{H}), 5.49$ (s, $0.4 \mathrm{H}), 5.66(\mathrm{~s}, 0.6 \mathrm{H}), 7.26-7.52(\mathrm{~m}, 5 \mathrm{H}) .{ }^{13} \mathrm{C}$ NMR (DMSO- $\left.d_{6}\right) \delta$ 35.7, 36.2, 65.9, 66.2, 71.8, 72.2, 126.9, 128.1, 128.8, 140.1.

\subsection{2. (2RS, 4R)-2-Phenylthiazolidine-4-carboxylic acid ethyl} ester (2)

Thionyl chloride (3.6 ml, $48.9 \mathrm{mmol})$ diluted in ethanol $(30 \mathrm{~mL})$ was maintained at $0{ }^{\circ} \mathrm{C}$. After the addition of (2RS, 4R)-2-Phenylthiazolidine-4-carboxylic acid $(5.00 \mathrm{~g}, 23.9 \mathrm{mmol})$, the mixture was warmed to room temperature and stirred overnight. The solvent was evaporated under reduced pressure and the resulting crude was dissolved in dichloromethane, washed with a saturated solution of $\mathrm{NaHCO}_{3}(3 \times 20 \mathrm{~mL})$ and water $(3 \times 20 \mathrm{~mL})$. The organic layer was dried $\left(\mathrm{MgSO}_{4}\right)$ and concentrated under reduced pressure to yield the expected compound as yellow oil $(4.14 \mathrm{~g}, 73 \%)$.

${ }^{1} \mathrm{H}$ NMR $\left(\mathrm{CDCl}_{3}\right) \delta 1.31(\mathrm{~m}, 3 \mathrm{H}) 3.11(\mathrm{dd}, J=12.0 \mathrm{~Hz}, J=9.0 \mathrm{~Hz}$, $0.6 \mathrm{H}), 3.19(\mathrm{dd}, J=9.0 \mathrm{~Hz}, J=6.0 \mathrm{~Hz}, 0.4 \mathrm{H}), 3.39(\mathrm{dd}, J=9.0 \mathrm{~Hz}$, $J=6.0 \mathrm{HZ}, 0.4 \mathrm{H}), 3.47(\mathrm{dd}, J=9.0 \mathrm{~Hz}, J=6.0 \mathrm{~Hz}, 0.6 \mathrm{H}), 3.98(\mathrm{dd}$, $J=9.0 \mathrm{~Hz}, J=6.0 \mathrm{~Hz}, 0.6 \mathrm{H}), 4.07(\mathrm{dd}, J=12.0 \mathrm{~Hz}, J=9.1 \mathrm{~Hz}, 0.4 \mathrm{H}$ ), $4.25(\mathrm{~m}, 2 \mathrm{H}), 5.57(\mathrm{~s}, 0.6 \mathrm{H}), 5.83(\mathrm{~s}, 0.4 \mathrm{H}), 7.33-7.55(\mathrm{~m}, 5 \mathrm{H}) .13 \mathrm{C}$ NMR $\left(\mathrm{CDCl}_{3}\right) \delta 14.0,38.3,39.7,61.8,65.5,66.1,71.2,72.5,127.0$, 127.6, 127.9, 128.2, 130.3, 130.6.

LC-MS: ELSD 98\%, rt = $5.73 \mathrm{~min} ., \mathrm{m} / z 238(\mathrm{M}+\mathrm{H})^{+}$.

\subsection{3. (2RS, 4R)-2-Phenyl-3-propionyl-thiazolidine-4-carboxylic acid ethyl ester (3)}

Propiolic acid $(0.246 \mathrm{~mL}, 4 \mathrm{mmol})$ was slowly added to a solution of dicyclohexylcarbodiimide $(0.99 \mathrm{~g}, 4.8 \mathrm{mmol})$ in anhydrous $\mathrm{CH}_{2} \mathrm{Cl}_{2}(10 \mathrm{~mL})$ at $0{ }^{\circ} \mathrm{C}$. After $10 \mathrm{~min}$, a solution of $(2 R S, 4 R)-2$-Phenylthiazolidine-4-carboxylate ethyl ester $(0.949 \mathrm{~g}, 4 \mathrm{mmol})$ in anhydrous $\mathrm{CH}_{2} \mathrm{Cl}_{2}(4 \mathrm{~mL})$ was added dropwise, and the mixture was first stirred at $0{ }^{\circ} \mathrm{C}$ for $1 \mathrm{~h}$, and then at room temprature overnight. The solution was filtered and the extract was evaporated under reduced pressure. The resulting crude was purified on silica gel, yielding a white solid $(0.833 \mathrm{~g}, 72 \%)$.

${ }^{1} \mathrm{H}$ NMR $(\mathrm{CDCl} 3) \delta 1.20-1.27(\mathrm{~m}, 3 \mathrm{H}), 2.97(\mathrm{~s}, 0.6 \mathrm{H}), 3.16(\mathrm{~s}$, $0.4 \mathrm{H}), 3.19(\mathrm{dd}, J=7.0 \mathrm{~Hz}, J=12.0 \mathrm{~Hz}, 0.4 \mathrm{H}), 3.29(\mathrm{dd}, J=7.0 \mathrm{~Hz}$, $J=12.0 \mathrm{~Hz}, 0.4 \mathrm{H}), 3.35(\mathrm{~d}, J=5.60 \mathrm{~Hz}, 1.2 \mathrm{H}), 4.15-4.25(\mathrm{~m}, 2 \mathrm{H})$, $4.91(\mathrm{t}, J=5.60 \mathrm{~Hz}, 0.6 \mathrm{H}), 5.18(\mathrm{t}, J=7.0 \mathrm{~Hz}, 0.4 \mathrm{H}), 6.28(\mathrm{~s}, 0.4 \mathrm{H})$, $6.40(\mathrm{~s}, 0.6 \mathrm{H}), 7.19-7.62(\mathrm{~m}, 5 \mathrm{H}) .13 \mathrm{C} \mathrm{NMR}\left(\mathrm{CDCl}_{3}\right) \delta 14.3,32.8$, 33.9, 62.4, 62.7, 64.1, 65.6, 66.6, 67.9, 75.9, 76.4, 79.6, 81.8, 127.1, 127.3, 128.4, 128.6, 140.5, 152.4, 169.3. LC-MS: ELSD 98\%, $\mathrm{rt}=9.82 \mathrm{~min} ., \mathrm{m} / \mathrm{z} 290(\mathrm{M}+\mathrm{H})^{+}$.

\subsection{Cell culture}

Cancer cells $(n=10)$ were cultured routinely at $37{ }^{\circ} \mathrm{C}$ under $5 \%$ $\mathrm{CO}_{2}$ in the standard medium ( $2 \mathrm{mM}$ L-glutamine, $0.1 \mathrm{mM}$ nonessential amino acids, 100 units/mL penicillin, $100 \mu \mathrm{g} / \mathrm{mL}$ streptomycin in DMEM, supplemented with 10\% FCS (Gibco, Invitrogen)).

\subsection{In vitro cell growth assay (Giemsa staining)}

Cells were plated into 24-well plates and grown overnight. Chemicals were dissolved in DMSO and added to the medium at a concentration of $4 \mathrm{mM}$ and $8 \mathrm{mM}$. After $48 \mathrm{~h}$ of additional incubation, attached cells were stained with Giemsa (Sigma-Aldrich) and photographed.

\subsection{Sulforhodamine B assay}

Cells were plated in 96-well plates (1000-5000 cell/well in $200 \mu \mathrm{L}$ ) and grown for $24 \mathrm{~h}$ at $37^{\circ} \mathrm{C}$ before being treated with various concentrations of the tested compounds (from 0.1 to $10 \mu \mathrm{M}$ ). After $72 \mathrm{~h}$ of incubation the medium was aspirated, washed once with $1 \times \mathrm{PBS}\left(\mathrm{CaCl}_{2^{-}}, \mathrm{MgCl}_{2}\right.$-free) (Gibco, Invitrogen), and then $50 \mu \mathrm{L}$ of a cold $\left(4^{\circ} \mathrm{C}\right)$ solution of $10 \%(\mathrm{v} / \mathrm{v})$ trichloroacetic acid (MERCK) was added. Microplates were left for $1 \mathrm{~h}$ at $4{ }^{\circ} \mathrm{C}$. After aspiration of the solution, plates were washed five times with deionized water and left to dry. Fifty microliter of a $0.4 \%(\mathrm{~m} / \mathrm{v})$ of sulforhodamine (Sigma-Aldrich) in $1 \%$ acetic acid solution were added to each well and left at room temperature for $10 \mathrm{~min}$. Then the sulforhodamine B (SRB) solution was removed and the plates washed five times with $1 \%$ acetic acid before air-drying. Bound sulforhodamine B was solubilized in a $200 \mu \mathrm{L} 10 \mathrm{mM}$ Tris-base solution and the plates were left on a plate shaker for $10 \mathrm{~min}$. The absorbance was read in a 96-well plate reader at $515 \mathrm{~nm}$.

\subsection{Cytotoxicity assessment with real-time cell analyzer}

For real-time cell analysis (RT-CA, xCELLigence, Roche Applied Sciences), $50 \mu \mathrm{L}$ of cell culture media was initially added to each well of the 96X e-plate (Roche Applied Sciences) to get a steady impedance value. Then, human cancer cells were seeded in $150 \mu \mathrm{L}$ of media in varying concentrations of 1000 to 5000 cells/ well. The attachment, spreading, and proliferation of the cells were monitored every 30 min using the RT-CA in a cell culture incubator. Approximately $24 \mathrm{~h}$ after seeding, when the cells were in the log growth phase, they were treated with ALC67. For the control, only DMSO was added to a well. Each experiment was repeated at least three times. The electronic readout (cell-sensor impedance) was displayed as an arbitrary unit called the cell index (CI). The $\mathrm{CI}$ value was noted every $10 \mathrm{~min}$ for the first $24 \mathrm{~h}$ and then every $30 \mathrm{~min}$. The cell inhibition rate $(\%)=(1-\mathrm{CI}$ treated cells $/$ CIDMSO) $\times 100$.

\subsection{Detection of apoptosis}

Cells were seeded on coverslips in 6-well plates. After overnight culture, cells were exposed to ALC67 at a concentration of $5 \mathrm{mM}$ for $48 \mathrm{~h}$. To determine nuclear condensation by Hoescht 33258 (Sigma-Aldrich) staining, coverslips were washed twice with icecold PBS, fixed in $1 \mathrm{~mL}$ of cold methanol for $10 \mathrm{~min}$, and then incubated with $3 \mu \mathrm{g} / \mathrm{mL}$ of Hoescht 33258 for $5 \mathrm{~min}$ in darkness. The coverslips were then rinsed with distilled water, mounted on glass microscopic slides using 50\% glycerol, and examined under fluorescent microscopy. A TUNEL assay was performed using the in situ Cell Death Detection kit (Roche), according to the manufacturer's recommendations.

\subsection{Immunofluorescence assay for cytochrome $C$ release}

Cytoplasmic cytochrome c was tested by immunofluorescence staining, as described by Achenbach et al. The cells were grown on coverslips and fixed with $4 \%$ paraformaldehyde for $30 \mathrm{~min}$ at room temperature, then rinsed with PBS and permeabilized in ice-cold acetone for $10 \mathrm{~min}$. After washing with PBS, the cells were blocked with $3 \%$ BSA in PBS for $1 \mathrm{~h}$ at $37^{\circ} \mathrm{C}$ and incubated with anti-cytochrome c monoclonal antibody (BD Biosciences) overnight at $4{ }^{\circ} \mathrm{C}$. After washing with PBS, the cells were incubated with FITC-conjugated anti-mouse secondary antibody for $1 \mathrm{~h}$, in darkness, at room temperature. The resulting coverslips were washed three times with PBS and mounted on glass microscopic slides to be analyzed by fluorescent microscopy. 


\subsection{Fluorescence-activated cell sorting analysis}

Human cancer cell lines of interest were inoculated into 100$\mathrm{mm}$ culture dishes (100,000-200,000 cells/dish). Twenty-four hours later, growth medium was replaced by starvation medium ( $1 \% \mathrm{FBS}, 1 \% \mathrm{P} / \mathrm{S}, 1 \% \mathrm{NEAA}$ in DMEM) and inoculation was continued for an additional day. Cells were then treated with the cytotoxic compound at the desired concentration and incubated for $24 \mathrm{~h}$ before being collected by trypsinization. Pellets were washed with $1 \times$ PBS. After centrifugation of the cell suspension, the supernatant was discarded and the pellets were fixed in icecold $70 \%$ ethanol and stored at $4{ }^{\circ} \mathrm{C}$. Before the analysis, the pellets were re-suspended in $500 \mu \mathrm{L}$ of propidium iodide solution (25 $\mu \mathrm{L}$ PI (Sigma-Aldrich), $5 \mu \mathrm{L} 10 \mathrm{mg} / \mathrm{mL}$ RNAase A (Fermentas), $0.25 \mu \mathrm{L}$ Triton $\mathrm{X}-100$, and $469.75 \mu \mathrm{L}$ ice-cold PBS) and incubated for $40 \mathrm{~min}$ at $37^{\circ} \mathrm{C}$ in darkness. After an addition of $3 \mathrm{~mL}$ of PBS, the suspension was centrifuged and the pellets re-suspended in $500 \mu \mathrm{L}$ of PBS. Cell cycle analysis was conducted with FACSCalibur (Becton Dickinson). Data were analyzed and graphs were prepared using CellQuest software purchased from Becton Dickinson.

\subsection{Caspase activity assay}

Cells were plated in 96-well plates in the presence of one of caspase- 8 inhibitor peptide z-IETD-fmk $(50 \mu \mathrm{M})$, caspase- 9 inhibitor peptide $z$-IETD-fmk $(50 \mu \mathrm{M})$, caspase-3 inhibitor peptide z-DEVD-fmk $(50 \mu \mathrm{M})$, or the DMSO control. After $24 \mathrm{~h}$ of incubation at $37^{\circ} \mathrm{C}$, the medium was removed and replaced with $100 \mu \mathrm{L}$ of a fresh medium containing, in addition to the respective inhibitors, the tested compound (ALC67) at a concentration of $10 \mu \mathrm{M}$ except for the normalization controls. After $12 \mathrm{~h}$ of incubation, caspase activity was measured using the Caspase Glo Assay Kit (Promega) according to the manufacturer's recommendations.

\subsection{Western blotting}

Huh7 cells were treated with $2.5 \mu \mathrm{M}$ and $5 \mu \mathrm{M}$ ALC67 or DMSO control for 6, 12 and $24 \mathrm{~h}$. Then equal amounts of cell lysates were solubilized with $1 \mathrm{x}$ loading dye, SRA (or DTT). The protein concentration of the lysates was determined by the Bradford assay. Then the lysates were denatured for $10 \mathrm{~min}$ in $100^{\circ} \mathrm{C}$. 20-50 $\mathrm{ng}$ of proteins were loaded to the gels. NuPAGE NOVEX pre-cast gel system was used for throughout the western blot analysis procedures according to the manufacturer's protocol. Depending on the protein length MOPS or MES running buffer was used. After electrophoresis, the proteins were transferred to nitrocellulose membrane ( $30 \mathrm{~V}, 90 \mathrm{~min}$ ) followed by incubation in blocking solution ( $5 \%$ BSA in $1 \times$ TBS-T $(0.1 \%$ tween $)$ ) for one hour at room temperature. Cleaved caspase-9 (Santa Cruz, sc-22182), caspase-3 (Cell signaling, 9662S) and caspase-8 (IC12) (Cell signaling, 9746S) primary antibodies were used in a ratio of $1: 500$ in $5 \%$ BSA-TBS-T, O/N $+4{ }^{\circ} \mathrm{C}$. Secondary antibodies, anti-goat (Sigma, A8919), anti-rabbit (Sigma, A6154), anti-mouse (Sigma, A0168), were applied in $1: 5000$ dilutions in 5\%BSA-TBS-T $(0.1 \%)$ for one hour at room temperature. Actin (Sigma, A5441) primary antibody for equal loading analysis was used in 1:5000 dilution in 5\% milk-powder in TBS$\mathrm{T}(0.1 \%)$ for $1 \mathrm{~h}$ at room temperature. For visualization of the results, chemiluminescence was performed with ECL+ kit according to the manufacturer's protocol. The chemiluminescence light was captured on X-ray film.

\section{Acknowledgments}

This work was supported by grants from Turkish State Planning Organization (DPT) KANILTEK project, Bilkent University local funds, and funds from CNRS and INSERM. F.E. Onen-Bayram was supported by the French Embassy in Turkey/ARC and the French Ministry of Education, respectively. The authors thank Bilge Ozturk for laboratory assistance, Zehra Onen for statistical analysis, and Ms. R. Nelson for editing the English of the final version of our manuscript.

\section{References}

1. Joshi, S.; Tiwari, A. K.; Mondal, B.; Sharma, A. Clin. Chim. Acta 2011, 412, 217

2. Karagiannis, G. S.; Pavlou, M. P.; Diamandis, E. P. Mol. Oncol. 2010, 4, 496.

3. Liu, R.; Wang, K.; Yuan, K. F.; Wei, Y. Q.; Huang, C. H. Expert Rev. Proteomics 2010, 7,411 .

4. Schreiber, S. L. Bioorg. Med. Chem. 1998, 6, 1127.

5. Lafanechere, L. Comb. Chem. High Throughput Screening 2008, 11, 617.

6. Crews, C. M.; Splittgerber, U. Trends Biochem. Sci. 1999, 24, 317.

7. Scapin, G. Curr. Drug Targets 2006, 7, 1443.

8. Bredel, M.; Jacoby, E. Nat Rev Genet. 2004, 4, 262.

9. Azim, H.; Azim, H. A. Oncology 2008, 74, 150.

10. Browne, B. C.; O’Brien, N.; Duffy, M. J.; Crown, J.; O’Donovan, N. Curr. Cancer Drug Targets 2009, 9, 419.

11. Lubbert, M.; Muller-Tidow, C.; Hofmann, W. K.; Koeffler, H. P. J. Cell. Biochem. 2008, 104, 2059.

12. Cohen, M. H.; Johnson, J. R.; Pazdur, R. Clin. Cancer Res. 2005, 11, 12.

13. Hunter, A. M.; LaCasse, E. C.; Korneluk, R. G. Apoptosis 2007, 12, 1543.

14. Varfolomeev, E.; Vucic, D. Future Oncol. 2011, 7, 633.

15. Gududuru, V.; Hurh, E.; Dalton, J. T.; Miller, D. D. Bioorg. Med. Chem. Lett. 2004, $14,5289$.

16. Gududuru, V.; Hurh, E.; Dalton, J. T.; Miller, D. D. J. Med. Chem. 2005, 48, 2584.

17. Gududuru, V.; Hurh, E.; Sullivan, J.; Dalton, J. T.; Miller, D. D. Bioorg. Med. Chem. Lett. 2005, 15, 4010.

18. Li, W.; Wang, Z.; Gududuru, V.; Zbytek, B.; Slominski, A. T.; Dalton, J. T.; Miller, D. D. Anticancer Res. 2007, 27, 883.

19. Li, W.; Lu, Y.; Wang, Z.; Dalton, J. T.; Miller, D. D. Bioorg. Med. Chem. Lett. 2007, $17,4113$.

20. Lu, Y.; Wang, Z.; Li, C. M.; Chen, J. J.; Dalton, J. T.; Li, W.; Miller, D. D. Bioorg. Med. Chem. 2010, 18, 477.

21. Onen, F. E.; Boum, Y.; Jacquement, C.; Spanedda, M. V.; Jaber, N.; Scherman, D.; Myllykallio, H.; Herscovici, J. Bioorg. Med. Chem. Lett. 2008, 18, 3628.

22. Desai, S.; Desai, P. B.; Desai, K. R. Heterocycl. Commun. 1999, 5, 385.

23. Verma, A.; Saraf, S. K. Eur. J. Med. Chem. 2008, 43, 897.

24. Havrylyuk, D.; Zimenkovsky, B.; Lesyk, R. Phosphorus Sulfur and Silicon and the Related Elements 2009, 184, 638.

25. Lv, P. C.; Zhou, C. F.; Chen, J.; Liu, P. G.; Wang, K. R.; Mao, W. J.; Li, H. Q.; Yang, Y.; Xiong, J.; Zhu, H. L. Bioorg. Med. Chem. 2010, 18, 314.

26. Wang, S. B.; Zhao, Y. F.; Zhang, G. G.; Lv, Y. X.; Zhang, N.; Gong, P. Eur. J. Med. Chem. 2011, 46, 3509 .

27. Li, W. T.; Wu, W. H.; Tang, C. H.; Tai, R.; Chen, S. T. Acs Comb. Sci. 2011, 13, 72.

28. Girard, C.; Onen, E.; Aufort, M.; Beauviere, S.; Samson, E.; Herscovici, J. Org. Lett. 2006, 8, 1689.

29. Jlalia, I.; Beauvineau, C.; Beauviere, S.; Onen, E.; Aufort, M.; Beauvineau, A.; Khaba, E.; Herscovici, J.; Meganem, F.; Girard, C. Molecules 2010, 15, 3087.

30. Hengartner, M. O. Nature 2000, 407, 770.

31. Nicholson, D. W. Cell Death Differ 1999, 6, 1028.

32. Fujita, E.; Egashira, J.; Urase, K.; Kuida, K.; Momoi, T. Cell Death Differ 2001, 8, 335.

33. Denault, J. B.; Eckelman, B. P.; Shin, H.; Pop, C.; Salvesen, G. S. Biochem. J. 2007, $405,11$.

34. Conrad, D. M.; Robichaud, M. R.; Mader, J. S.; Boudreau, R. T.; Richardson, A. M.; Giacomantonio, C. A.; Hoskin, D. W. Int. J. Oncol. 2008, 32, 1325.

35. von Haefen, C.; Wieder, T.; Essmann, F.; Schulze-Osthoff, K.; Dörken, B.; Daniel, P. T. Oncogene 2003, 22, 2236.

36. Wieder, T.; Essmann, F.; Prokop, A.; Schmelz, K.; Schulze-Osthoff, K.; Beyaert, R.; Dörken, B.; Daniel, P. T. Blood 2001, 97, 1378.

37. Hattori, H.; Tanaka, M.; Fukushima, M.; Sasaki, T.; Matsuda, A. J. Med. Chem. 1996, 39, 5005

38. Takatori, S.; Kanda, H.; Takenaka, K.; Wataya, Y.; Matsuda, A.; Fukushima, M.; Shimamoto, Y.; Tanaka, M.; Sasaki, T. Cancer Chemother. Pharmacol. 1999, 44, 97.

39. Kazuno, H.; Shimamoto, Y.; Tsujimoto, H.; Fukushima, M.; Matsuda, A.; Sasakio, T. Oncol. Rep. 2007, 17, 1453.

40. Jackson, R. C.; Jackman, A. L.; Calvert, A. H. Biochem. Pharmacol. 1983, 32, 3783.

41. Jackman, A. L.; Taylor, G. A.; Oconnor, B. M.; Bishop, J. A.; Moran, R. G.; Calvert, A. H. Cancer Res. 1990, 50, 5212

42. Piper, J. R.; McCaleb, G. S.; Montgomery, J. A.; Kisliuk, R. L.; Gaumont, Y. Sirotnak, F. M. J. Med. Chem. 1982, 25, 877.

43. Degraw, J. I.; Colwell, W. T.; Piper, J. R.; Sirotnak, F. M. J. Med. Chem. 1993, 36, 2228

44. O'Connor, O. A.; Hamlin, P. A.; Portlock, C.; Moskowitz, C. H.; Noy, A.; Straus, D. J.; MacGregor-Cortelli, B.; Neylon, E.; Sarasohn, D.; Dumetrescu, O.; Mould, D. 
R.; Fleischer, M.; Zelenetz, A. D.; Sirotnak, F.; Horwitz, S. Br. J. Haematol. 2007, 139, 425.

45. O'Connor, O. A.; Horwitz, S.; Hamlin, P.; Portlock, C.; Moskowitz, C. H.; Sarasohn, D.; Neylon, E.; Mastrella, J.; Hamelers, R.; MacGregor-Cortelli, B.; Patterson, M.; Seshan, V. E.; Sirotnak, F.; Fleisher, M.; Mould, D. R.; Saunders, M.; Zelenetz, A. D. J. Clin. Oncol. 2009, 27, 4357.
46. O’Connor, O. A.; Pro, B.; Pinter-Brown, L.; Bartlett, N.; Popplewell, L.; Coiffier B.; Lechowicz, M. J.; Savage, K. J.; Shustov, A. R.; Gisselbrecht, C.; Jacobsen, E.; Zinzani, P. L.; Furman, R.; Goy, A.; Haioun, C.; Crump, M.; Zain, J. M.; Hsi, E.; Boyd, A.; Horwitz, S. J. Clin. Oncol. 2011, 29, 1182.

47. Laborde, E. Cell Death Differ. 2010, 17, 1373. 